\title{
Acrosome damage of ram spermatozoa during dilution, cooling and freezing
}

\author{
F. Tasseron, D. Amir and H. Schindler \\ Agricultural Research Organization, Institute of Animal Science, The Volcani Center, \\ P.O.B. 6, Bet Dagan, Israel
}

Although a fertilization rate similar to that of fresh semen has been obtained with frozen ram semen (Colas, 1975), a low lambing rate is reported in the majority of the studies so far published (Salamon $\&$ Visser, 1974). The low fertility of the frozen ram semen has been attributed to a failure of sperm transport in the female (Lightfoot \& Salamon, 1970), to a reduced viability of the spermatozoa in the genital tract of the ewe (Mattner, Entwistle \& Martin, 1969), or, at least in part, to the acrosomal damage caused by freezing (Watson \& Martin, 1972).

In the present study an attempt was made to determine how much damage is caused to ram spermatozoa during each of the dilution, cooling and freezing-thawing stages. Sperm damage was determined by light and electron microscopy and the fertility of the frozen-thawed spermatozoa was determined in a small-scale insemination trial.

The ejaculates, obtained with an artificial vagina, were diluted in the raffinose-sodium citrate-egg yolk diluent containing $5 \%$ glycerol, frozen and stored as described by Lightfoot \& Salamon (1970). Because of the variability in the freezing ability of the spermatozoa between different rams and different ejaculates, only 3 out of the 9 rams tested were used and the ejaculates were those showing a sperm survival of at least $30 \%$ after freezing and thawing. The ejaculates were diluted to concentrations of $1 \times 10^{9}$ and $2 \times 10^{9}$ cells $/ \mathrm{ml}$ and each pellet $(0.12 \mathrm{ml})$ therefore contained either $120 \times 10^{6}$ or $240 \times 10^{6}$ spermatozoa. Thawing was carried out in $0.1 \mathrm{ml}$ thawing solution (Lightfoot \& Salamon, 1970) at $70^{\circ} \mathrm{C}$ for $15 \mathrm{sec}$. This combination of temperature and time was found to be superior to combinations of $60^{\circ} \mathrm{C}$ for $20 \mathrm{sec}, 50^{\circ} \mathrm{C}$ for $25 \mathrm{sec}$ and $37^{\circ} \mathrm{C}$ for $45-60 \mathrm{sec}$.

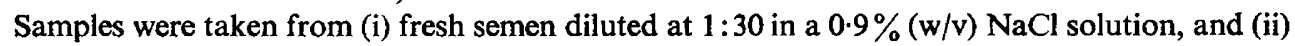
semen diluted with the freezing solution (a) immediately, (b) after cooling for $5 \mathrm{~h}$, and (c) after freezing and thawing. For light microscopy the smears were stained with Giemsa and the acrosomal defects (Watson \& Martin, 1972) were recorded for 200 spermatozoa which were randomly observed under an immersion objective $(\times 1000)$. For electron microscopy, samples were stained with a $2 \%$ phosphotungstic acid solution and mounted on grids. At least 100 of such negatively stained spermatozoa were observed with a JEM 7 microscope at a magnification of 6000-9000 and the cells with a damaged acrosome were recorded.

The acrosomal damage caused to the spermatozoa during the different stages of the freezing process is shown in Table 1 . Since no differences in the results were found between the two sperm concentrations $\left(1 \times 10^{9}\right.$ and $2 \times 10^{9}$ cells $\left./ \mathrm{ml}\right)$ at which the semen was diluted and pelleted, the data were pooled. It appears that the spermatozoa were damaged during all the stages of dilution, cooling

Table 1. Percentage (mean \pm S.E.M., no. of replicates within parentheses) of ram spermatozoa with damaged acrosomes after dilution, cooling and freezing -thawing

\begin{tabular}{lcc}
\hline \multicolumn{1}{c}{ Treatment } & Light microscopy & Electron microscopy \\
\hline $\begin{array}{l}\text { Fresh semen + saline }(1: 30) \\
\text { Fresh semen + freezing solution }\end{array}$ & $8 \cdot 0 \pm 0 \cdot 4^{\mathrm{a}}(12)$ & $14 \cdot 7 \pm 0.9^{\mathrm{a}}(6)$ \\
$\quad$ & $24 \cdot 8 \pm 1 \cdot 3^{\mathrm{b}}(24)$ & $30 \cdot 2 \pm 2 \cdot 1^{\mathrm{b}}(12)$ \\
$\quad$ used immediately & $33 \cdot 6 \pm 1 \cdot 8^{\mathrm{bc}}(24)$ & $40 \cdot 5 \pm 3 \cdot 1^{\mathrm{b}}(12)$ \\
used after cooling & $39 \cdot 8 \pm 0 \cdot 7^{\mathrm{c}}(56)$ & $68 \cdot 1 \pm 1 \cdot 2^{\mathrm{c}}(28)$ \\
\hline used after freezing and thawing & &
\end{tabular}

For values within columns, those with different superscripts differ significantly $(P<0.05)$, according to Duncan's multiple range test. 
and freezing and thawing, resulting in a cumulative acrosomal damage of about $40 \%$ detected by light microscopy and about $70 \%$ detected by electron microscopy. The large additional damage detected by electron microscopy after freezing and thawing consisted mainly of moderate bubbling and swelling of the acrosome. The fact that about $50 \%$ of the damaged spermatozoa were damaged only by dilution and cooling suggests the necessity of improving the diluent.

Ninety-two ewes were inseminated either at the second oestrus after synchronization or during a natural oestrus. Heat detection was carried out with aproned rams at 8 -h intervals. The ewes were inseminated either once, $16 \mathrm{~h}$ after they had been first detected in oestrus (16-24 h after the onset of oestrus), or twice, with the second insemination being given $8 \mathrm{~h}$ after the first. The insemination dose was $240 \times 10^{6}$ spermatozoa contained either in two pellets of a sperm concentration of $1 \times 10^{9} \mathrm{cells} / \mathrm{ml}$ thawed in $0.2 \mathrm{ml}$ thawing solution, or in one pellet of sperm concentration of $2 \times 10^{9}$ cells $/ \mathrm{ml}$ thawed in $0.1 \mathrm{ml}$ thawing solution. Accordingly, the inseminate volumes were 0.44 or $0.22 \mathrm{ml}$. In the double inseminations a total of $480 \times 10^{6}$ spermatozoa was inseminated. The inseminations were carried out within 2 months of the semen being frozen.

The overall lambing percentage was low (19 lambings) and no significant differences were obtained by using different sperm concentrations, insemination doses or double inseminations. With a mean recovery rate of $34 \%$ motile spermatozoa in the present study, it was calculated that about $80 \times 10^{6}$ motile cells were inseminated at each insemination. When a similar number of unfrozen spermatozoa were inseminated 16-24 h after the onset of oestrus, it was found to be sufficient for a good conception rate (Schindler \& Amir, 1973). However, since damage to the acrosome, although causing infertility (Healey, 1969) does not in itself interfere with motility, it is possible that the $68 \%$ spermatozoa with damaged acrosomes were distributed equally between the motile and immotile sperm populations. Therefore, it is conceivable that the inseminate contained as few as $25 \times 10^{6}$ intact motile spermatozoa. Additional loss of spermatozoa could perhaps be caused by drainage of part of the sperm suspension which was not held back in the anterior vagina and the first cervical folds. In these locations probably no more than $0 \cdot 10-0.15 \mathrm{ml}$ can be deposited (Hawk \& Conley, 1971; Andersen \& Aamdal, 1972), whereas the inseminate volumes in the present work were, by necessity, 0.22 and $0.44 \mathrm{ml}$. The low conception rate with frozen semen in this study can, therefore, be explained by considerable sperm damage and the need to increase the inseminate volume for thawing beyond the holding capacity of the female genital tract.

The assistance of $\mathrm{H}$. Gassitua and Y. Dimmerman is gratefully acknowledged. This paper is contribution No. 114-E, 1977 series, from the Agricultural Research Organization, The Volcani Center, Bet Dagan, Israel.

\section{References}

ANDERSEN, K. \& AAmDAL, J. (1972) Artificial insemination with frozen semen in sheep in Norway. Wld Rev. Anim. Prod. 8, 77-79.

Colas, G. (1975) Effect of freezing temperature, addition of glycerol and dilution on the survival and fertilizing ability of deep frozen ram semen. $J$. Reprod. Fert. 42, 277-285.

HAWK, H.W. \& CONLEY, H.H. (1971) Loss of spermatozoa from the reproductive tract of the ewe and intensification of sperm "breakage" by progestagen. J. Reprod. Fert. 27, 339-347.

HeALeY, P. (1969) Effect of freezing on the ultrastructure of the spermatozoa of some domestic animals. J. Reprod. Fert. 18, 21-27.

Lightfoot, R.J. \& SAlamon, S. (1970) Fertility of ram spermatozoa frozen by the pellet method. I. Transport and viability of spermatozoa within the genital tract of the ewe. J. Reprod. Fert. 22, 385-398.

Mattiner, P.E., Entwistle, K.W. \& Martin, I.C.A. (1969) Passage survival and fertility of deep-frozen ram semen in the genital tract of the ewe. Aust. J. biol. Sci. 22, 181-187.

SALAMON, S. \& Visser, D. (1974) Recent advances in the deep-freezing of ram semen. S. Afr. J. Sci. 4, 275-288.

Schindler, H. \& Amir, D. (1973) The conception rate of ewes in relation to sperm dose and time of insemination. J. Reprod. Fert. 34, 191-196.

Watson, P.F. \& MARTIN, I.C.A. (1972) A comparison of changes in the acrosomes of deep frozen ram and bull spermatozoa. J. Reprod. Fert. 28, 99-101. 